\title{
Abcg2 transporter affects plasma, milk and tissue levels of meloxicam
}

Alba M. Garcia-Lino ${ }^{a}$, Esther Blanco-Paniagua ${ }^{a}$, Elsa N. Astorga-Simon ${ }^{a}$, Dafne Garcia-Mateos $^{\mathrm{a}}$, Indira Alvarez-Fernandez ${ }^{\mathrm{a}}$, Ana I. Alvarez ${ }^{\mathrm{a}}$ and Gracia Merino ${ }^{\mathrm{a}}$

${ }^{a}$ Department of Biomedical Sciences-Physiology, Veterinary Faculty, Instituto de Desarrollo Ganadero y Sanidad Animal (INDEGSAL), Universidad de León, Campus de Vegazana, León, Spain.

\section{Corresponding author:}

Dra. Gracia Merino

Department of Biomedical Sciences-Physiology, Veterinary Faculty, University of Leon 24071, Campus de Vegazana, Leon, Spain.

Phone: +34-987291263; Fax: +34-987291267; E-mail: gmerp@unileon.es

Funding sources: This study was supported by the research projects AGL201565626-R (MINECO/FEDER, UE) and RTI2018-100903-B-I00 (AEI/FEDER, UE); and by the predoctoral grants from the Ministry of Economy, Industry and Competitiveness (BES-2016-077235 grant to AMGL), and from Spanish Ministry of Education, Culture and Sport (FPU14/05131 grant to DGM AND FPU18/01559 grant to EBP); and the Junta de Castilla y Leon and European Regional Development Fund (Post-Doctoral Fellowship LE011P17 grant to IAF).

Conflict of interest: none 


\section{ABSTRACT}

ATP-binding cassette (ABCG2) is an efflux transporter that extrudes xenotoxins from cells in liver, intestine, mammary gland, brain and other organs, affecting the pharmacokinetics, brain accumulation and secretion into milk of several compounds, including antitumoral, antimicrobial and anti-inflammatory drugs. The aim of this study was to investigate whether the widely used anti-inflammatory drug meloxicam is an Abcg2 sustrate, and how this transporter affects its systemic distribution. Using polarized ABCG2-transduced cell lines, we found that meloxicam is efficiently transported by murine Abcg2 and human ABCG2. After oral administration of meloxicam, the area under the plasma concentration-time curve in $\mathrm{Abcg}^{-/-}$mice was 2-fold higher than in wild type mice $(146.06 \pm 10.57 \mu \mathrm{g} \cdot \mathrm{h} / \mathrm{ml}$ versus $73.80 \pm 10.00$ $\mu \mathrm{g} \cdot \mathrm{h} / \mathrm{ml}$ ). Differences in meloxicam distribution were reported for several tissues, with a 20 -fold higher concentration in the brain of $\mathrm{Abcg}^{-/}$compared to wild-type mice. Meloxicam secretion into milk was also affected by the transporter, with a 2.5 -fold higher milk-to-plasma ratio in wild-type compared with $\mathrm{Abcg}^{-/ /}$lactating female mice $(0.58 \pm 0.08$ versus $0.23 \pm 0.06)$. We conclude that Abcg2 is an important determinant of the plasma and brain distribution of meloxicam and is clearly involved in its secretion into milk.

Keywords: $A B C G 2$, meloxicam, transport, pharmacokinetics, tissue distribution.

Abbreviations: ABC, ATP-binding cassette; AUC, Area under curve; CNS, Central Nervous System; COX, cyclooxygenase enzymes; HPLC, High performance liquid chromatography; MDCKII, Madin-Darby canine kidney epithelial cells; NSAID, nonsteroidal anti-inflammatory drug. 


\section{INTRODUCTION}

Non-steroidal anti-inflammatory drugs (NSAIDs) are widely used due to their analgesic, anti-inflammatory and antipyretic properties by inhibition of cyclooxygenase enzymes (COX) [1,2]. Meloxicam is a NSAID of the acidic enolcarboxamide class [3], with preferential selectivity towards COX-2 relative to COX-1 [4]. Furthermore, meloxicam has a second mechanism of action which activates the nitric oxic-cyclic GMP pathway and plays and important role in its analgesic effect. In this way, meloxicam opens potassium channels activated by calcium channels, which generates a peripheral antinociceptive effect [5]. The use of meloxicam is increasing due to its high intrinsic activity. It is widely used in the treatment of osteoarthritis, rheumatoid arthritis and neurophatic pain in humans $[6,7]$. Its efficacy in sciatica and lumbago has also been reported [8,9]. Moreover, meloxicam is also used in veterinary therapy, including treatments for lactating cattle [10] in which a withdrawal period is established. The unintended presence of drugs in milk, including NSAIDs, may also imply a risk to newborns and dairy product consumers $[11,12]$.

The main route of administration of meloxicam is oral, but it can be also administered by intravenous or intramuscular route. However, regardless of the route, absorption of this compound is almost complete [13]. After oral administration, meloxicam, as with the majority of NSAIDs, is absorbed in stomach and small intestine mucosa and metabolized in the liver by cytochrome P-450 $2 \mathrm{C}[14,15]$ to 4 pharmacologically inactive metabolites which are excreted in both urine and faeces [13]. In this metabolic pathway, meloxicam may interact with drug transporters, including ATPbinding cassette $(\mathrm{ABC})$ transporters that may affect its pharmacokinetics and efficacy. In fact, interaction between some NSAIDs drugs and ABCG2, a described 
member of the ABC transporter family [16], has been reported. Several NSAIDs such as piroxicam (also belonging to the family of oxicam), ibuprofen, naproxen, salicylate, among others, have been previously described as ABCG2 inhibitors, affecting the renal excretion of methotrexate [17]. In addition, diclofenac has been described as an efficient in vitro substrate for both murine and human ABCG2 [18]. Furthermore, ABCG2 is also involved in the distribution and elimination of diclofenac glucuronides in mice [19]. Recent studies have demonstrated that ABCG2 is involved in the secretion of flunixin and its main metabolite, $5 \mathrm{OH}$ - flunixin, into milk [20]. Although meloxicam is a widely used drug in the medical and veterinary field, there are no studies of its interaction with $A B C$ transporters which might influence its drug pharmacokinetics.

The ABCG2 protein, localized in the apical membrane of epithelial cells, extrudes a wide range of xenotoxins from cells in several organs such as intestine, kidney and liver, among others. As a consequence, ABCG2 restricts the uptake of its transported substrates in the gut, thereby limiting their absorption, and mediating their distribution, hepatobiliary excretion and intestinal elimination $[21,22]$. Several in vivo studies demonstrated that ABCG2 also limits the foetal and brain penetration of its substrates $[21,23]$. This protein also contributes to drug-drug interactions, and therefore affects drug efficacy and drug adverse effects [24,25].

Moreover, ABCG2 is highly expressed in the lactating mammary gland and participates in the active secretion of several natural compounds [26,27] and xenobiotics, such as antibiotics [28,29], carcinogens [30] and antiparasitics [31], into milk. In the case of lactating animals it is a determinant factor in the presence of several compounds in dairy consumed milk [11] due to potential adverse effects in the consumer. 
Our aim was to investigate the role of ABCG2 in oral and intravenous pharmacokinetics, tissue distribution and secretion into milk of meloxicam, using in vitro and in vivo tools, including Abcg2 knock-out mice.

\section{MATERIALS AND METHODS}

\subsection{Standards and Chemicals}

Reference standards of meloxicam and flunixin were purchased from Sigma-Aldrich (St. Luis, MO). Ko143 was purchased from Tocris (Bristol, United Kingdom). For the pharmacokinetic studies, meloxicam solutions (Metacam® $2 \mathrm{mg} / \mathrm{ml}$ i.v. solution and Metacam® $1.5 \mathrm{mg} / \mathrm{ml}$ oral solution) were obtained from Boehringer (Ingelheim, Germany) All the other chemicals were analytical grade and obtained from commercial sources.

\subsection{Cell Cultures}

Madin-Darby Canine Kidney (MDCKII) cells and their murine Abcg2 and human ABCG2 transduced subclones were provided by Dr. A.H. Schinkel, Netherlands Cancer Institute, Amsterdam. Culture conditions have been previously described [32].

\subsection{Transport studies}

Transepithelial transport assays using Transwell plates were carried out as described elsewhere [33] with minor modifications. Cells (passage 20-35) were grown for 3 days after seeding on microporous polycarbonate membrane filters at a density of $1.0 \times 10^{6}$ cells per well. To check the tightness of the monolayer, transepithelial resistance was measured in each well using a Millicell ERS ohmmeter (Millipore, 
Burlington, MA). Two hours before the start of the experiment, medium at both the apical and basolateral sides of the monolayer was replaced with $2 \mathrm{ml}$ of OptiMEM medium (Invitrogen, Carlsbad, CA), and either with or without the specific ABCG2 inhibitor Ko143 $(1 \mu \mathrm{M})$. The experiment was started $(t=0)$ by replacing the medium in either the apical or basolateral compartment with fresh OptiMEM medium, either with or without $1 \mu \mathrm{M}$ Ko143 and containing $30 \mu \mathrm{M}$ meloxicam. Cells were incubated at $37^{\circ} \mathrm{C}$ in $5 \% \mathrm{CO}_{2}$ and aliquots of $100 \mu$ of culture media were taken at $\mathrm{t}=1,2,3$ and 4 $\mathrm{h}$ in the opposite compartment and this volume was replaced with fresh medium. At the end of the experiment confluence of the monolayer was checked with Lucifer Yellow permeability assays [31] with minor modifications. The presence of meloxicam in the opposite compartment was measured by HPLC. Active transport across MDCKII monolayers was expressed by the relative transport ratio, defined as the apically directed transport percentage divided by the basolaterally directed translocation percentage, after 4 hours.

\subsection{Animals}

Animals were housed and handled according to institutional guidelines complying with European legislation (2010/63/EU). Experimental procedures were approved by the Animal Care and Use Committee of the University of León and the Junta de Castilla y Leon (ULE_011_2016). Animals used were male or lactating female Abcg2${ }^{1-}$ and wild- type mice, all of $>99 \%$ FVB genetic background and between 8 and 12 weeks of age in the case of males, and between 9 and 17 weeks of age of the lactating females. The animals, kindly provided by A. H. Schinkel (The Netherlands Cancer Institute, Amsterdam, The Netherlands), were kept in a temperaturecontrolled environment with $12 \mathrm{~h}$ light/12 $\mathrm{h}$ dark cycle, and received a standard diet and water ad libitum. 


\subsection{Pharmacokinetic Experiment}

For i.v. administration of $10 \mathrm{mg} / \mathrm{kg}$ meloxicam, $5 \mu \mathrm{l}$ of Metacam® $(2 \mathrm{mg} / \mathrm{ml})$ commercial solution/g body weight was injected into the tail of mice lightly anesthetized with isoflurane. Blood samples were collected at different time points over $5 \mathrm{~h}$ by cardiac puncture under anesthesia with isoflurane. For oral administration of $15 \mathrm{mg} / \mathrm{kg}$ meloxicam, $10 \mu \mathrm{l}$ of Metacam® $(1.5 \mathrm{mg} / \mathrm{ml})$ commercial solution $/ \mathrm{g}$ body weight was dosed by gavage into the stomach. Blood samples were collected at different time points over $24 \mathrm{~h}$ by cardiac puncture under anesthesia with isoflurane. Organs were harvested after euthanasia by cervical dislocation at the $4 \mathrm{~h}$ time point. Heparinized blood samples were centrifuged immediately at $3000 \mathrm{~g}$ for $15 \mathrm{~min}$ and stored at $-20{ }^{\circ} \mathrm{C}$ until HPLC analysis. Three to six animals were used for each time point.

\subsection{Milk Secretion Experiments}

For milk secretion experiments, pups approximately 10 days old were separated from their mother approximately $4 \mathrm{~h}$ before milk collection. For administration of meloxicam $10 \mathrm{mg} / \mathrm{kg}, 5 \mu \mathrm{l}$ of Metacam® $(2 \mathrm{mg} / \mathrm{ml})$ commercial solution $/ \mathrm{g}$ body weigh was injected into the tail of mice 30 minutes before milk and blood collection. To stimulate milk secretion, oxytocin $(200 \mu \mathrm{l}$ of $1 \mathrm{lU} / \mathrm{ml}$ solution) was administered subcutaneously to lactating mothers $10 \mathrm{~min}$ before sample collection. At the indicated time, milk was collected from the mammary glands by gentle vacuum suction after anesthesia with isoflurane. Blood samples were collected by cardiac puncture under anesthesia with isoflurane. At the end of the experiment mice were killed by cervical 
dislocation. Heparinized blood samples were centrifuged immediately at $3000 \mathrm{~g}$ for 15 min to obtain plasma. Milk and plasma were stored at $-20^{\circ} \mathrm{C}$ until HPLC analysis.

\subsection{High Performance Liquid Chromatography (HPLC) Analysis}

The chromatographic system used in samples analysis consisted of a Waters 2695 separation module and a Waters 2998 UV photodiode array detector.

The methodology for the extraction of the samples was adapted from Chen et al. [34] and is based on the use of an organic solvent, such as acetonitrile, for protein precipitation. Tissue samples were homogenized with potassium phosphate buffer $(\mathrm{pH} 3)$ at $0,1 \mathrm{~g}$ tissue $/ 1 \mathrm{ml}$. To each $100 \mu \mathrm{l}$ aliquot of sample (homogenized tissue, plasma or milk), $10 \mu \mathrm{l}$ of a flunixin solution $(100 \mu \mathrm{l} / \mathrm{ml})$ was added as an internal standard. The mixture was vortexed vigorously and $400 \mu \mathrm{l}$ of acetonitrile was added for protein precipitation. After vortexing for $1 \mathrm{~min}$ and centrifuging at $6000 \mathrm{~g}$ for $5 \mathrm{~min}$, the supernatant was evaporated with $\mathrm{N}_{2}$ and the dry residue was re-dissolved in methanol $(100 \mu \mathrm{l})$. After centrifugation at $10000 \mathrm{~g}$ for $1 \mathrm{~min}$ the samples were analysed into the HPLC system. Samples from the transport assays were not processed, and $50 \mu \mathrm{l}$ of the culture media was directly injected into the HPLC system. Separation of the samples was performed on a reverse-phase column (Phenomenex® Synergi 4u Hydro - RP 80A, 250 x $4.60 \mathrm{~mm}$ ). The composition of mobile phase was $10 \mathrm{mM}$ potassium phosphate buffer, $\mathrm{pH}$ 2.1: acetonitrile (33:67) for animal samples and $4 \%$ glacial acetic acid:acetonitrile (50:50) for culture samples. The flow rate of the mobile phase was set to $1.2 \mathrm{ml} / \mathrm{min}$. UV absorbance was measured at $365 \mathrm{~nm}$. Standard samples in the appropriate drug-free matrix were prepared yielding a concentration range from 0.019 to $15 \mu \mathrm{g} / \mathrm{ml}$, with correlation coefficients $>0.99$. The limit of quantification (LOQ) was $0.01 \mu \mathrm{g} / \mathrm{ml}$ and the limit of 
detection (LOD) was $0.005 \mu \mathrm{g} / \mathrm{ml}$ for cell culture samples; LOQ $0.03 \mu \mathrm{g} / \mathrm{ml}$ and LOD $0.01 \mu \mathrm{g} / \mathrm{ml}$ for plasma samples; LOQ $0.02 \mu \mathrm{g} / \mathrm{ml}$ and LOD $0.007 \mu \mathrm{g} / \mathrm{ml}$ for milk samples and for tissues LOQ $0.001-0.02 \mu \mathrm{g} / \mathrm{ml}$ and LOD $0.001-0.01 \mu \mathrm{g} / \mathrm{ml}$. LOD and LOQ calculations were performed by the method described by Taverniers et al. [35].

\subsection{Statistical analysis}

Comparisons between groups were made using the Student's t-test (normal variables) and the Mann-Whitney $U$ test (not normally distributed variables). All analyses were carried out on the assumed significance level of $p \leq 0.05$ using SPSS Statistics software (v. 24.0; IBM, Armonk, New York, NY, USA). The results are shown as mean \pm standard deviation (SD).

\section{RESULTS}

\subsection{In Vitro Transport of Meloxicam}

To determine whether murine Abcg2 and human ABCG2 were involved in meloxicam in vitro transport, MDCKII and its subclones transduced with murine Abcg2 and human ABCG2 cDNAs were used in transepithelial transport studies.

In the parental MDCKII cells, apical to basal directed translocation was equal to basal to apical translocation of meloxicam (Fig. 1A). Nevertheless, apically directed translocation highly increased and basolaterally directed translocation drastically decreased in the Abcg2 transduced cells compared with the MDCKII parental cell line (Fig. 1A). Relative efflux transport ratio at 4 hours was significantly higher in MDCKIIAbcg2 $(32.46 \pm 9.02)$ compared to parental cells $(1.11 \pm 0.15)$. When the cells transduced with human $A B C G 2$ were used, the difference with the parental cells in 
the apical directional transport was lower than in the case of the murine Abcg2transduced cell line. Even so, apically directed translocation increased and basolaterally directed translocation decreased in these cells compared with the MDCKII parental cell line (Fig. 1A), and a significant difference between transport ratio obtained for human ABCG2 transduced cells and parental cells was found (4.10 \pm 1.05 vs $1.11 \pm 0.15$, respectively). Furthermore, when the selective ABCG2 inhibitor Ko143 was used, this ABCG2-mediated transport was inhibited (Fig. 1B) for both types of transduced cells, resulting in a vectorial translocation pattern equal to that of the MDCKII parental cell line. These results show highly efficient in vitro transport of meloxicam by murine Abcg2 and human ABCG2.

\subsection{Plasma Pharmacokinetics of Meloxicam in $\mathrm{Abcg2}^{-/-}$and Wild-Type Mice}

To assess whether in vitro ABCG2-mediated transport of meloxicam was also relevant in vivo, plasma pharmacokinetics of meloxicam in $\mathrm{Abcg}^{-/-}$and wild-type mice was studied. Plasma concentration of meloxicam was determined as a function of time, after i.v. and oral administration of meloxicam in both types of mice (Fig. 2A and Fig. 2B, respectively). For i.v. administration (10 mg/kg), no significant differences between the two types of mice were found at any time tested (Fig. 2A). Nor were significant differences found in the area under the plasma concentrationtime curve (AUC) between wild type and Abcg $2^{-/-}$mice $(44.01 \pm 1.94 \mu \mathrm{g} \cdot \mathrm{h} / \mathrm{ml}$ vs $45.07 \pm 2.10 \mu \mathrm{g} \cdot \mathrm{h} / \mathrm{ml}$ ). Nevertheless, after oral administration of $15 \mathrm{mg} / \mathrm{kg}$ meloxicam (Fig. 2B), AUC of $\mathrm{Abcg2}^{-/}$mice was significantly higher compared with the wild-type mice $(146.03 \pm 10.57 \mu \mathrm{g} \cdot \mathrm{h} / \mathrm{ml}$ vs $73.80 \pm 10.00 \mu \mathrm{g} \cdot \mathrm{h} / \mathrm{ml}$, respectively). Significant differences in plasma concentration of meloxicam between both types of mice were 
also found at several time points $(1,2,3,5,6$ and 8 hours). These results clearly show that Abcg2 affects the oral pharmacokinetics of meloxicam.

\subsection{Effect of Abcg2 on Tissue Distribution of Meloxicam}

To investigate the role of Abcg2 in tissue distribution of meloxicam, meloxicam concentration was measured in several tissues and small intestinal content at $4 \mathrm{~h}$ after oral administration, when the variability between samples was lowest. Meloxicam concentration in brain, liver and testis from $\mathrm{Abcg}^{-{ }^{--}}$mice was significantly higher compared to wild-type mice (Fig. 3), which indicates that the accumulation of meloxicam in these tissues is affected by Abcg2. A relative effect of Abcg2 was also found in the small intestine and in the small intestinal content of $A b c g 2^{-/-}$, although differences were not statistically significant. Finally, no differences between $\mathrm{Abcg} 2^{-/-}$ and wild-type mice were observed in concentration of meloxicam in the kidney, which indicates that Abcg2 does not affect the elimination of meloxicam in this organ.

This differential tissue distribution of meloxicam further substantiates that meloxicam is an in vivo substrate of Abcg2 and that Abcg2 affects systemic exposure to this drug.

\subsection{Secretion of Meloxicam into Milk in $\mathrm{Abcg}^{-/-}$and Wild-type Mice}

To test whether Abcg2 plays a role in the secretion of meloxicam into milk, $10 \mathrm{mg} / \mathrm{kg}$ meloxicam was administered i.v. to lactating $\mathrm{Abcg}^{-{ }^{--}}$and wild-type female mice, and milk and blood samples were collected 30 min after administration and analysed (Fig. 4). A similar concentration of meloxicam in plasma was obtained in both types of animals $(11.78 \pm 1.16 \mu \mathrm{g} / \mathrm{ml}$ vs. $10.04 \pm 2.31 \mu \mathrm{g} / \mathrm{ml})$. Conversely, the concentration of meloxicam was more than 3-fold lower in the milk of $\mathrm{Abcg}^{-/-}$mice compared with wild-type mice $(6.74 \pm 0.63 \mu \mathrm{g} / \mathrm{ml}$ vs $2.36 \pm 0.81 \mu \mathrm{g} / \mathrm{ml})$. Therefore, milk-to-plasma 
ratio of meloxicam in wild-type was almost 3 -fold higher compared to $\mathrm{Abcg}^{-1-}$ lactating mice $(0.58 \pm 0.08 \mu \mathrm{g} / \mathrm{ml}$ vs $0.23 \pm 0.07 \mu \mathrm{g} / \mathrm{ml})$. These results clearly show that Abcg2 plays an important role in the active secretion of meloxicam into milk.

\section{DISCUSSION}

In this work, we demonstrate that the NSAID meloxicam is transported in vitro by murine Abcg2 and human ABCG2, and that murine Abcg2 affects the oral pharmacokinetics and milk secretion of this drug. Efficient in vitro transport of meloxicam by murine Abcg2 and more moderate transport by human ABCG2 is demonstrated (Fig. 1). Different efficiency in the expression between murine and human ABCG2 construct may cause interspecies differences. However, differences in affinity/selectivity of ABCG2 and Abcg2 substrates cannot be discarded. This hypothesis has been also proposed for other ABCG2 substrates [36,37]. Previous studies have demonstrated that other NSAIDs were also in vitro substrates for the ABCG2 transporter. For instance, diclofenac was identified as an efficiently transported substrate for murine and human ABCG2, with estimated transport ratios clearly lower (between 2 and 4) [38] than those obtained in our assay (Fig. 1A). Therefore, meloxicam is transported in vitro more efficiently than diclofenac, for both variants.

To extrapolate in vitro results to the in vivo situation, pharmacokinetics studies of meloxicam were performed using $\mathrm{Abcg}^{-/-}$mice in which the two most common routes of administration of the drug were tested at the therapeutic doses. The first step in the study of in vivo interaction between drugs and transporters, such us Pglycoprotein or ABCG2, is usually the use of knock-out mice [39]. This is a widely used model in drug pharmacokinetics and secretion into milk studies [40]. 
For oral administration, wild-type mice showed lower plasma levels and AUC compared with $\mathrm{Abcg}^{-/-}$(Fig. 2A). This finding indicates that intestinal Abcg2 may restrict meloxicam oral bioavailability by reducing its intestinal absorption. However, we observed no significant differences in small intestinal tissue between wild-type and $\mathrm{Abcg}^{-1-}$ mice, probably due to the high interindividual variability. Hepatic elimination seems not to be affected by this transporter since no significant differences between wild-type and $\mathrm{Abcg}^{-1-}$ mice in plasma concentration were observed after intravenous administration of meloxicam (Fig. 2A). In fact, although a significantly higher accumulation of meloxicam was observed in liver of $\mathrm{Abcg}^{-/-}$mice (Fig. 3) after oral administration, these differences could be attributable to higher plasma levels in $\mathrm{Abcg2}^{-/}$up to this point (Fig. 2B). Toxic effects of meloxicam have been shown in liver [41]. Regardless of whether the differences observed were caused by local or systemic effects of Abcg2, an accumulation of meloxicam in liver is affected by the expression of this transporter and may be relevant in the assessment of hepatotoxicity of meloxicam. Something similar occurred in testis. However, no differences between wild-type and $A b c g 2^{-/-}$mice were observed in kidney, so Abcg2 does not influence renal elimination of meloxicam.

Our results obtained from the brain are clinically relevant, since an almost 20-fold higher accumulation in this organ was observed in $\mathrm{Abcg}^{-/-}$compared with wild-type mice (Fig. 3). This difference cannot be attributable to the plasma difference, which was only 2 -fold at this time point $(4 \mathrm{~h})$. This result reveals that Abcg2 restricts brain accumulation of meloxicam in mice. Several studies provide a protective role for meloxicam in neuroinflammation processes $[42,43]$. In addition, a recent study suggests that meloxicam may prevent the development of neuropathic pain by reducing neuroinflammation and oxidative stress in the spinal cord [44] and in the 
brain [45]. Considering that an association between brain degenerative diseases, such as Alzheimer's disease, Parkinson's disease and Huntington's diseases, with oxidative stress exists [46], meloxicam could be a promising treatment for them. In fact, an improvement in symptoms of Alzheimer's disease has been reported in a mouse model with this drug [47]. Nevertheless, meloxicam has difficult in crossing the blood-brain barrier (BBB) [48]. In this work, we have shown that ABCG2 plays an important role in the passage of meloxicam through BBB and its accumulation in the central nervous system. Several studies have demonstrated the limiting role of ABCG2 in the brain penetration of many drugs $[49,50]$ and how transporter inhibition [51,52] or reduced expression due to genetic variants [24] can improve drug therapies related to the central nervous system. We therefore hypothesized that inhibition of ABCG2 could increase brain accumulation of meloxicam, and consequently, improve the potential treatment or prevention of neurodegenerative diseases with this drug.

Our results show Abcg2 affects systemic and tissue distribution of meloxicam. Therefore, the potential presence of Abcg2 inhibitors or genetic variants may affect its therapeutic role or side effects.

The influence of Abcg2 in meloxicam secretion into milk was also studied. Our data undoubtedly show that Abcg2 plays a major role in the secretion of meloxicam into the milk, as indicated by the 3-fold difference in milk-to-plasma ratio between $\mathrm{Abcg}^{-1-}$ and wild-type mice (Fig. 4). This difference is similar to the values obtained previously in our group for another substrate belonging to the NSAID family, flunixin [20]. NSAID transport in the mammary gland can have clinical, toxicological and nutritional implications. The FDA does not advise administration of meloxicam in nursing mothers, due to its milk secretion and potential side effects [53]. Moreover, 
this drug is regulated for its veterinary use in food animals with an established maximum limit of residues in milk [54,55], although the role of ruminant ABCG2 in the presence of milk residues of meloxicam needs further studies to be elucidated. Note that differences in ABCG2 activity or genetic ABCG2 polymorphism [56], not only in the mother but also in the infant, may vary effective exposure of the infant.

In conclusion, this study has demonstrated that $A B C G 2$ is clearly involved in the active in vitro transport of meloxicam by both human and murine variants. Furthermore, our results support the fact that ABCG2 is an important determinant in the oral pharmacokinetics, tissue distribution and milk secretion of meloxicam.

\section{Acknowledgments}

We thank Dr. AH. Schinkel (The Netherlands Cancer Institute, Amsterdam, The Netherlands) who provided parental MDCKII cells and its murine Abcg2 and human ABCG2 transduced subclones; and Abcg2 knock-out mice. We are grateful to Prof. James McCue for assistance in language editing. 


\section{REFERENCES}

[1] G. Engelhardt, R. Bögel, C. Schnitzer, R. Utzmann, Meloxican: Influence on arachidonic acid metabolism, Biochem. Pharmacol. 51 (1996) 21-28. https://doi.org/10.1016/0006-2952(95)02111-6.

[2] P. Lees, J. Giraudel, M.F. Landoni, P.L. Toutain, PK-PD integration and PK-PD modelling of nonsteroidal anti-inflammatory drugs: principles and applications in veterinary pharmacology, J. Vet. Pharmacol. Ther. 27 (2004) 491-502. https://doi.org/10.1111/j.1365-2885.2004.00618.x.

[3] H.K. Han, H.K. Choi, Improved absorption of meloxicam via salt formation with ethanolamines, Eur. J. Pharm. Biopharm. 65 (2007) 99-103. https://doi.org/10.1016/J.EJPB.2006.07.003.

[4] M. Edfawy, M.H. Hassan, A. Mansour, A.A. Hamed, H.A.A. Amin, Meloxicam Modulates Oxidative Stress Status, Inhibits Prostaglandin E2, and Abrogates Apoptosis in Carbon Tetrachloride-Induced Rat Hepatic Injury, Int. J. Toxicol. 31 (2012) 276-286. https://doi.org/10.1177/1091581812442939.

[5] M.I. Ortiz, G. Castañeda-Hernández, V. Granados-Soto, Pharmacological evidence for the activation of $\mathrm{Ca} 2+$-activated $\mathrm{K}+$ channels by meloxicam in the formalin test., Pharmacol. Biochem. Behav. 81 (2005) 725-31. https://doi.org/10.1016/j.pbb.2005.05.008.

[6] E. Nagy, E. Vajda, C. Vari, S. Sipka, A.-M. Fárr, E. Horváth, Meloxicam ameliorates the cartilage and subchondral bone deterioration in monoiodoacetate-induced rat osteoarthritis, PeerJ. 5 (2017) e3185. https://doi.org/10.7717/peerj.3185. 
[7] A. Bekker, C. Kloepping, S. Collingwood, Meloxicam in the management of post-operative pain: Narrative review, J. Anaesthesiol. Clin. Pharmacol. 34 (2018) 450-457. https://doi.org/10.4103/joacp.JOACP_133_18.

[8] B. Borghi, L. Aurini, P.F. White, A. Mordenti, F. Lolli, R. Borghi, M. Martignani, T. Greggi, Long-lasting beneficial effects of periradicular injection of meloxicam for treating chronic low back pain and sciatica, Minerva Anestesiol. 79 (2013) $370-8$.

[9] A.E. Karateev, A.M. Lila, E.Y. Pogozheva, E.S. Filatova, V.N. Amirdzhanova, The efficacy of meloxicam in acute back pain: results of an observational noninterventional multicenter study, Zhurnal Nevrol. i Psikhiatrii Im. S.S. Korsakova. 118 (2018) 24. https://doi.org/10.17116/jnevro20181186124.

[10] E. Medicines Agency, Metacam / European Medicines Agency, (n.d.). https://www.ema.europa.eu/en/medicines/veterinary/EPAR/metacam (accessed August 5, 2019).

[11] A.M. García-Lino, I. Álvarez-Fernández, E. Blanco-Paniagua, G. Merino, A.I. Álvarez, Transporters in the Mammary Gland—Contribution to Presence of Nutrients and Drugs into Milk, Nutrients. 11 (2019) E2372. https://doi.org/10.3390/nu11102372.

[12] European Food Safety Authority (EFSA), Report for 2016 on the results from the monitoring of veterinary medicinal product residues and other substances in live animals and animal products, EFSA Support. Publ. 15 (2018). https://doi.org/10.2903/sp.efsa.2018.en-1358.

[13] D. NM, N. Skjodt, Clinical pharmacokinetics of meloxicam. A cyclo-oxygenase2 preferential nonsteroidal anti-inflammatory drug, Clin. Pharmacol. 36 (1999) 
115-26. https://doi.org/10.2165/00003088-199936020-00003.

[14] D. Burukoglu, C. Baycu, F. Taplamacioglu, E. Sahin, E. Bektur, Effects of nonsteroidal anti-inflammatory meloxicam on stomach, kidney, and liver of rats, Toxicol. Ind. Health. 32 (2016) 980-986. https://doi.org/10.1177/0748233714538484.

[15] C. Wen, Z. Zhuang, H. Song, S. Tong, X. Wang, Y. Lin, H. Zhan, Z. Chen, L. $\mathrm{Hu}$, Metabolism of liver CYP450 and ultrastructural changes after long-term administration of aspirin and ibuprofen, Biomed. Pharmacother. 108 (2018) 208-215. https://doi.org/10.1016/j.biopha.2018.08.162.

[16] J.D. Allen, A.H. Schinkel, Multidrug resistance and pharmacological protection mediated by the breast cancer resistance protein (BCRP/ABCG2), Mol. Cancer Ther. 1 (2002) 427-34.

[17] A.A.K. El-Sheikh, J.J.M.W. van den Heuvel, J.B. Koenderink, F.G.M. Russel, Interaction of nonsteroidal anti-inflammatory drugs with multidrug resistance protein (MRP) 2/ABCC2- and MRP4/ABCC4-mediated methotrexate transport, J. Pharmacol. Exp. Ther. 320 (2007) 229-35. https://doi.org/10.1124/jpet.106.110379.

[18] J.S. Lagas, C.M. van der Kruijssen, K. van de Wetering, J.H. Beijnen, A.H. Schinkel, Transport of diclofenac by BCRP (ABCG2) and stimulation of MRP2(ABCC2-) mediated drug transport by diclofenac and benzbromarone, Drug Metab Dispos. 37 (2008) 129-136. https://doi.org/10.1124/dmd.108.023200.

[19] J.S. Lagas, R.W. Sparidans, E. Wagenaar, J.H. Beijnen, A.H. Schinkel, Hepatic Clearance of Reactive Glucuronide Metabolites of Diclofenac in the Mouse Is Dependent on Multiple ATP-Binding Cassette Efflux Transporters, 
Mol. Pharmacol. 77 (2010) 687-694. https://doi.org/10.1124/mol.109.062364.

[20] D. Garcia-Mateos, A.M. Garcia-Lino, I. Alvarez-Fernandez, E. BlancoPaniagua, A. de la Fuente, A.I. Alvarez, G. Merino, Role of ABCG2 in secretion into milk of the anti-inflammatory flunixin and its main metabolite: in vitro-in vivo correlation in mice and cows, Drug Metab. Dispos. 47 (2019) 516-24. https://doi.org/10.1124/dmd.118.085506.

[21] J.W. Jonker, J.W. Smit, R.F. Brinkhuis, M. Maliepaard, J.H. Beijnen, J.H. Schellens, A.H. Schinkel, Role of breast cancer resistance protein in the bioavailability and fetal penetration of topotecan, J. Natl. Cancer Inst. 92 (2000) $1651-6$.

[22] A. Kort, S. Durmus, R.W. Sparidans, E. Wagenaar, J.H. Beijnen, A.H. Schinkel, Brain and Testis Accumulation of Regorafenib is Restricted by Breast Cancer Resistance Protein (BCRP/ABCG2) and P-glycoprotein (P-GP/ABCB1), Pharm. Res. 32 (2015) 2205-2216. https://doi.org/10.1007/s11095-014-1609-7.

[23] S. van Hoppe, A. Jamalpoor, J.J.M. Rood, E. Wagenaar, R.W. Sparidans, J.H. Beijnen, A.H. Schinkel, Brain accumulation of osimertinib and its active metabolite AZ5104 is restricted by ABCB1 (P-glycoprotein) and ABCG2 (breast cancer resistance protein), Pharmacol. Res. 146 (2019).

https://doi.org/10.1016/j.phrs.2019.104297.

[24] K.L. Mealey, ABCG2 transporter: therapeutic and physiologic implications in veterinary species, J. Vet. Pharmacol. Ther. 35 (2012) 105-112. https://doi.org/10.1111/j.1365-2885.2011.01313.x.

[25] Á. Telbisz, C. Hegedüs, C. Özvegy-Laczka, K. Goda, G. Várady, Z. Takáts, E. Szabó, B.P. Sorrentino, A. Váradi, B. Sarkadi, Antibody binding shift assay for 
rapid screening of drug interactions with the human $A B C G 2$ multidrug transporter., Eur. J. Pharm. Sci. 45 (2012) 101-9.

https://doi.org/10.1016/j.ejps.2011.10.021.

[26] V. Miguel, J.A. Otero, R. García-Villalba, F. Tomás-Barberán, J.C. Espín, G. Merino, A.I. Álvarez, V. Miguel, J.A. Otero, R. García-Villalba, F. TomásBarberán, J.C. Espín, G. Merino, A.I. Álvarez, Role of ABCG2 in transport of the mammalian lignan enterolactone and its secretion into milk in abcg2 knockout mice, Drug Metab. Dispos. 42 (2014) 943-946. https://doi.org/10.1124/dmd.113.055970.

[27] D. García-Mateos, R. García-Villalba, J.A. Marañón, J.C. Espín, G. Merino, A.I. Álvarez, The Breast Cancer Resistance Protein (BCRP/ABCG2) influences the levels of enterolignans and their metabolites in plasma, milk and mammary gland, J. Funct. Foods. 35 (2017) 648-654. https://doi.org/10.1016/j.jff.2017.06.038.

[28] J.A. Otero, R. Real, A. de la Fuente, J.G. Prieto, M. Marques, A.I. Alvarez, G. Merino, The Bovine ATP-Binding Cassette Transporter ABCG2 Tyr581Ser Single-Nucleotide Polymorphism Increases Milk Secretion of the Fluoroquinolone Danofloxacin, Drug Metab. Dispos. 41 (2013) 546-549. https://doi.org/10.1124/dmd.112.049056.

[29] J.A. Otero, D. García-Mateos, A. de la Fuente, J.G. Prieto, A.I. Álvarez, G. Merino, Effect of bovine ABCG2 Y581S polymorphism on concentrations in milk of enrofloxacin and its active metabolite ciprofloxacin, J. Dairy Sci. 99 (2016) 5731-5738. https://doi.org/10.3168/jds.2015-10593.

[30] A.E. van Herwaarden, A.H. Schinkel, The function of breast cancer resistance 
protein in epithelial barriers, stem cells and milk secretion of drugs and xenotoxins, Trends Pharmacol. Sci. 27 (2006) 10-16.

[31] H. Mahnke, M. Ballent, S. Baumann, F. Imperiale, M. Von Bergen, C. Lanusse, A.L. Lifschitz, W. Honscha, S. Halwachs, The ABCG2 efflux transporter in the mammary gland mediates veterinary drug secretion across the blood-milk barrier into milk of dairy cows, Drug Metab. Dispos. 44 (2016) 700-708. https://doi.org/10.1124/dmd.115.068940.

[32] L. González-Lobato, R. Real, D. Herrero, A. de la Fuente, J.G. Prieto, M.M. Marqués, A.I. Álvarez, G. Merino, Novel in vitro systems for prediction of veterinary drug residues in ovine milk and dairy products, Food Addit. Contam. Part A. 31 (2014) 1026-1037. https://doi.org/10.1080/19440049.2014.908261.

[33] M. Perez, J.A. Otero, B. Barrera, J.G. Prieto, G. Merino, A.I. Alvarez, Inhibition of $A B C G 2 / B C R P$ transporter by soy isoflavones genistein and daidzein: Effect on plasma and milk levels of danofloxacin in sheep, Vet. J. 196 (2013) 203208.

[34] P.H. Chen, K.L. Boyd, E.K. Fickle, C.W. Locuson, Subcutaneous meloxicam suspension pharmacokinetics in mice and dose considerations for postoperative analgesia, J. Vet. Pharmacol. Ther. 39 (2016) 356-62. https://doi.org/10.1111/jvp.12297.

[35] E. Taverniers, I., De Loose, M., Van Bockstaele, Trends in quality in the analytical laboratory. II. Analytical method validation and quality assurance, TrAC Trends Anal. Chem. 23 (2004) 535-552.

https://doi.org/10.1016/J.TRAC.2004.04.001.

[36] G. Merino, The Breast Cancer Resistance Protein (BCRP/ABCG2) Affects 
Pharmacokinetics, Hepatobiliary Excretion, and Milk Secretion of the Antibiotic Nitrofurantoin, Mol. Pharmacol. 67 (2005) 1758-1764.

https://doi.org/10.1124/mol.104.010439.

[37] G. Merino, A.I. Álvarez, M.M. Pulido, A.J. Molina, A.H. Schinkel, J.G. Prieto, Breast cancer resistance protein (BCRP/ABCG2) transports fluoroquinolone antibiotics and affects their oral availability, pharmacokinetics, and milk secretion, Drug Metab. Dispos. 34 (2006) 690-695.

https://doi.org/10.1124/dmd.105.008219.

[38] J.S. Lagas, C.M.M. van der Kruijssen, K. van de Wetering, J.H. Beijnen, A.H. Schinkel, Transport of Diclofenac by Breast Cancer Resistance Protein (ABCG2) and Stimulation of Multidrug Resistance Protein 2 (ABCC2)-Mediated Drug Transport by Diclofenac and Benzbromarone, Drug Metab. Dispos. 37 (2009) 129-136. https://doi.org/10.1124/dmd.108.023200.

[39] K.M. Giacomini, S.-M. Huang, D.J. Tweedie, L.Z. Benet, K.L.R. Brouwer, X. Chu, A. Dahlin, R. Evers, V. Fischer, K.M. Hillgren, K.A. Hoffmaster, T. Ishikawa, D. Keppler, R.B. Kim, C.A. Lee, M. Niemi, J.W. Polli, Y. Sugiyama, P.W. Swaan, J.A. Ware, S.H. Wright, S.W. Yee, M.J. Zamek-Gliszczynski, L. Zhang, Membrane transporters in drug development, Nat. Rev. Drug Discov. 9 (2010) 215-236. https://doi.org/10.1038/nrd3028.

[40] M.L.H. Vlaming, J.S. Lagas, A.H. Schinkel, Physiological and pharmacological roles of ABCG2 (BCRP): recent findings in Abcg2 knockout mice, Adv. Drug Deliv. Rev. 61 (2009) 14-25. https://doi.org/10.1016/j.addr.2008.08.007.

[41] M. Lapeyre-Mestre, S. Grolleau, J.-L. Montastruc, Adverse drug reactions associated with the use of NSAIDs: a case/noncase analysis of spontaneous 
reports from the French pharmacovigilance database 2002-2006, Fundam. Clin. Pharmacol. 27 (2013) 223-230. https://doi.org/10.1111/j.14728206.2011.00991.x.

[42] M. Haile, A. Boutajangout, K. Chung, J. Chan, T. Stolper, N. Vincent, M. Batchan, J. D’Urso, Y. Lin, R. Kline, F. Yaghmoor, S. Jahfal, R. Kamal, W. Aljohani, T. Blanck, A. Bekker, T. Wisniewski, The Cox-2 Inhibitor Meloxicam Ameliorates Neuroinflammation and Depressive Behavior in Adult Mice after Splenectomy, J. Neurophysiol. Neurol. Disord. 3 (2016) 101.

[43] L. Han, Q. Ren, X. Bao, Y. Fen, Z. Mian, Y. Xue, Z. Zhi, Protective effect of meloxicam against acute radiation-induced brain injury in rats, Chinese J. Cell. Mol. Immunol. 30 (2014) 375-8.

[44] S. Kartha, C.L. Weisshaar, B.H. Philips, B.A. Winkelstein, Pre-treatment with Meloxicam Prevents the Spinal Inflammation and Oxidative Stress in DRG Neurons that Accompany Painful Cervical Radiculopathy, Neuroscience. 388 (2018) 393-404. https://doi.org/10.1016/j.neuroscience.2018.07.054.

[45] B. Dik, D. Coskun, E. Bahcivan, A. Er, Doxycycline and meloxicam can treat neuroinflammation by increasing activity of antioxidant enzymes in rat brain, Pak. J. Pharm. Sci. 32 (2019) 391-396.

[46] S. Manoharan, G.J. Guillemin, R.S. Abiramasundari, M.M. Essa, M. Akbar, M.D. Akbar, The Role of Reactive Oxygen Species in the Pathogenesis of Alzheimer's Disease, Parkinson's Disease, and Huntington's Disease: A Mini Review, Oxid. Med. Cell. Longev. 2016 (2016).

https://doi.org/10.1155/2016/8590578.

[47] F.R. laniski, C.B. Alves, C.F. Ferreira, V.C. Rech, L. Savegnago, E.A. Wilhelm, 
C. Luchese, Meloxicam-loaded nanocapsules as an alternative to improve memory decline in an Alzheimer's disease model in mice: involvement of $\mathrm{Na}+$, K+-ATPase, Metab. Brain Dis. 31 (2016) 793-802.

https://doi.org/10.1007/s11011-016-9812-3.

[48] I. Novakova, E.A. Subileau, S. Toegel, D. Gruber, B. Lachmann, E. Urban, C. Chesne, C.R. Noe, W. Neuhaus, Transport rankings of non-steroidal antiinflammatory drugs across blood-brain barrier in vitro models, PLoS One. 9 (2014). https://doi.org/10.1371/journal.pone.0086806.

[49] B. Poller, D. lusuf, R.W. Sparidans, E. Wagenaar, J.H. Beijnen, A.H. Schinkel, Differential impact of P-glycoprotein (ABCB1) and breast cancer resistance protein (ABCG2) on axitinib brain accumulation and oral plasma pharmacokinetics, Drug Metab. Dispos. 39 (2011) 729-35. https://doi.org/10.1124/dmd.110.037317.

[50] J. Wang, C. Gan, R.W. Sparidans, E. Wagenaar, S. van Hoppe, J.H. Beijnen, A.H. Schinkel, P-glycoprotein (MDR1/ABCB1) and Breast Cancer Resistance Protein (BCRP/ABCG2) affect brain accumulation and intestinal disposition of encorafenib in mice, Pharmacol. Res. 129 (2018) 414-423. https://doi.org/10.1016/j.phrs.2017.11.006.

[51] S.C. Tang, J.S. Lagas, N.A.G. Lankheet, B. Poller, M.J. Hillebrand, H. Rosing, J.H. Beijnen, A.H. Schinkel, Brain accumulation of sunitinib is restricted by Pglycoprotein (ABCB1) and breast cancer resistance protein (ABCG2) and can be enhanced by oral elacridar and sunitinib coadministration, Int. J. Cancer. 130 (2012) 223-33. https://doi.org/10.1002/ijc.26000.

[52] J.D. Strope, C.J. Peer, T.M. Sissung, O.M. Hall, P.A. Huang, E.M. Harris, K.R. 
Gustafson, C.J. Henrich, D.M. Sigano, G.T. Pauly, J.P. Schneider, S.E. Bates, W.D. Figg, Botryllamide $G$ is an ABCG2 inhibitor that improves lapatinib delivery in mouse brain, Cancer Biol. Ther. (2019) 1-8.

https://doi.org/10.1080/15384047.2019.1683324.

[53] Food and Drug Administration (FDA), Mobic® (meloxicam) tablets and oral suspension, n.d. www.fda.gov/medwatch. (accessed August 8, 2019).

[54] T.H. Swartz, H.H. Schramm, J.M. Bewley, C.M. Wood, K.E. Leslie, C.S. Petersson-Wolfe, Meloxicam administration either prior to or after parturition: Effects on behavior, health, and production in dairy cows, J. Dairy Sci. 101 (2018) 10151-10167. https://doi.org/10.3168/jds.2018-14657.

[55] A.N. Woodland, D. Van der Saag, B. Kimble, P.J. White, M. Govendir, S. Lomax, Plasma pharmacokinetic profile and efficacy of meloxicam administered subcutaneously and intramuscularly to sheep, PLoS One. 14 (2019). https://doi.org/10.1371/journal.pone.0215842.

[56] D. Hira, T. Terada, BCRP/ABCG2 and high-alert medications: Biochemical, pharmacokinetic, pharmacogenetic, and clinical implications, Biochem. Pharmacol. 147 (2018) 201-210. https://doi.org/10.1016/j.bcp.2017.10.004. 


\section{Figure legends}

Fig.1. Transepithelial transport assay of meloxicam at $30 \mu \mathrm{M}$ in parental MDCKII cells and its subclones transduced with murine Abcg2 and human ABCG2 in the absence (A) or presence (B) of Ko143 $1 \mu \mathrm{M}$ (ABCG2 inhibitor). The experiment was started $(t=0)$ by replacing the medium in either the apical or basolateral compartment with fresh culture medium containing $30 \mu \mathrm{M}$ of meloxicam with or without ABCG2 inhibitor Ko143 $1 \mu \mathrm{M}$. Aliquots of $100 \mu \mathrm{l}$ were taken from the opposite compartment at 1, 2, 3 and $4 \mathrm{~h}$ and measured by HPLC. The fraction of meloxicam transported to the acceptor compartment was presented as a percentage of total meloxicam added to the donor compartment at the beginning of the experiment. Results are represented as mean \pm SD. Ratio represents relative efflux transport ratio, apical directed translocation divided by basolateral directed translocation, at $4 \mathrm{~h}$. ( $\bullet)$ basolateral to apical transport; (o) apical to basolateral transport. $(n=3-6)$.

Fig. 2. Plasma concentration of meloxicam after IV administration of Metacam® (10 $\mathrm{mg} / \mathrm{kg}$ b.w.) (A) and oral administration (15 mg/kg b.w.) (B) to wild-type and $\mathrm{Abcg}^{-1-}$ mice. Plasma samples were collected at various time points over $5 \mathrm{~h}$ (IV) and $24 \mathrm{~h}$ (oral). Concentration of meloxicam in plasma were determined by HPLC. The results are presented as means \pm SDs. $\left(^{*}\right) \mathrm{P}<0.05$ significant differences between both groups of mice. $(n=3-6)$.

Fig. 3 Concentration of meloxicam in brain, small intestinal content, liver, small intestine (tissue), kidney and testis in wild-type and $\mathrm{Abcg}^{-/-}$male mice at $4 \mathrm{~h}$ after oral administration of a single dose of Metacam $\AA$ at $15 \mathrm{mg} / \mathrm{kg}$ b.w. were determinant by HPLC. Results are means \pm SDs. $\left(^{*}\right) P<0.05$ significant differences between both groups of mice $(n=4)$. 
Fig. 4. Plasma and milk concentration and milk-to-plasma ratio of meloxicam in wildtype and $\mathrm{Abcg}^{-/-}$mice after intravenous administration of Metacam ${ }^{\circledR}$ at a dose of 10 $\mathrm{mg} / \mathrm{kg}$ b.w. Plasma and milk were collected $30 \mathrm{~min}$ after administration and meloxicam concentration were determined by HPLC. Results are means \pm SDs. $\left({ }^{*}\right)$ $P<0.05$ significant differences between both groups of mice. $(n=4-6)$.

\section{Highlights}

- Meloxicam is efficiently in vitro transported by murine Abcg2 and human ABCG2

- Abcg2 transporter affects the oral pharmacokinetics of meloxicam in mice

- Abcg2 restricts brain accumulation of meloxicam in mice

- Abcg2 transporter plays a role in the secretion of meloxicam into milk in mice 


\section{Figure 1}
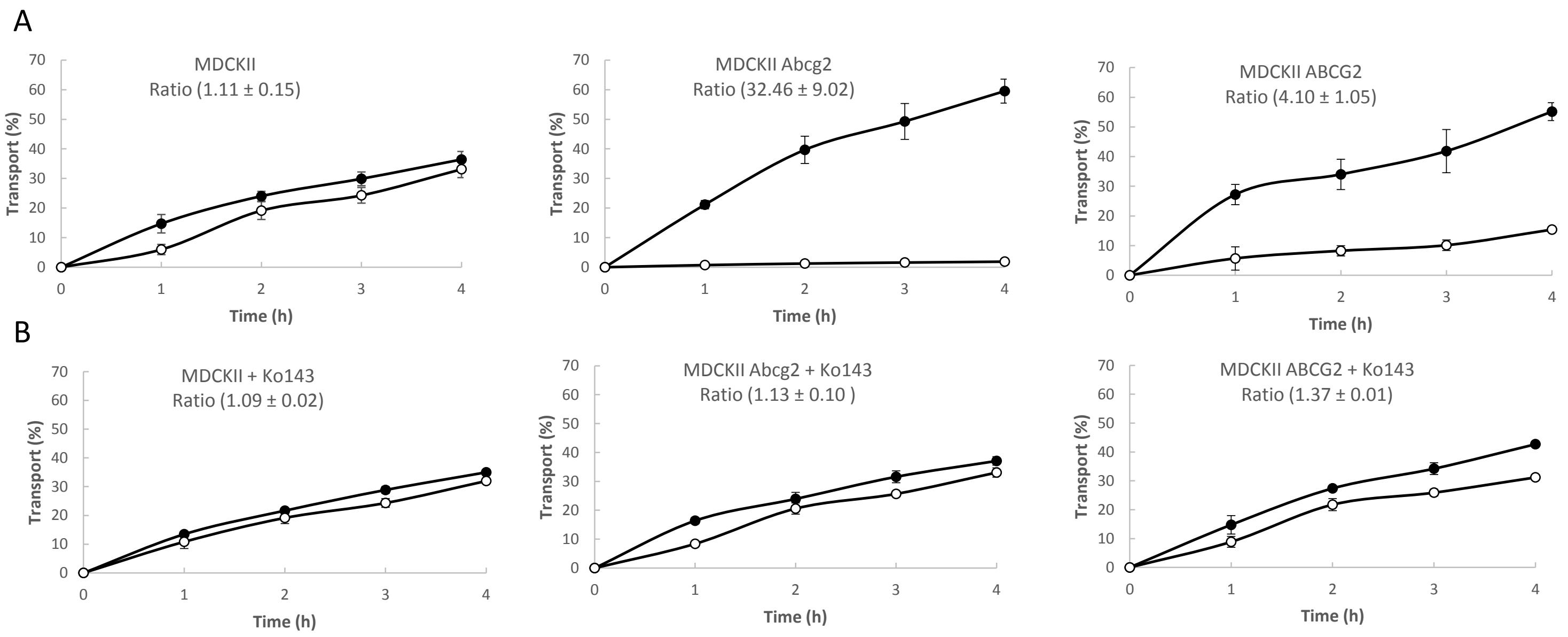
Figure 2
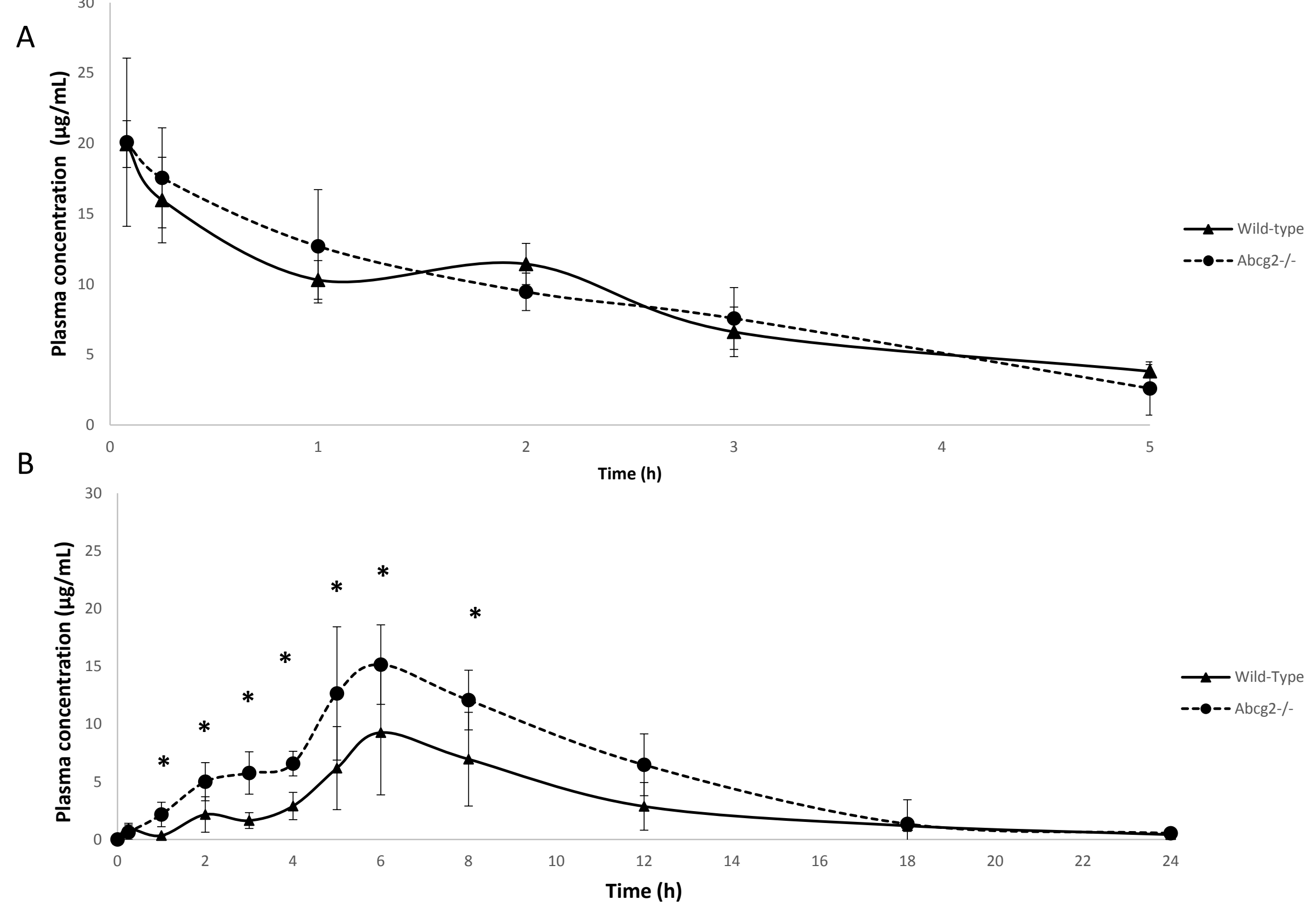


\section{Figure 3}
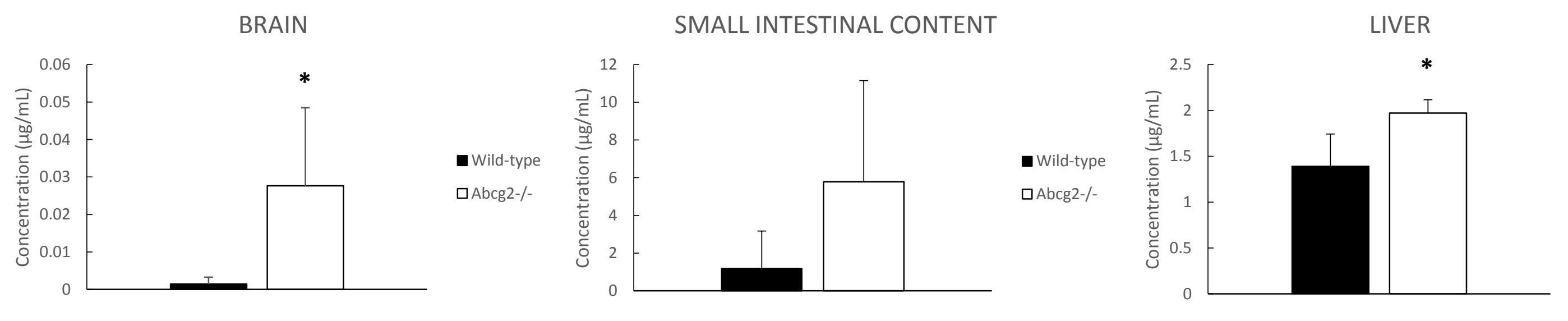

Wild-type

口Abcg2-/-
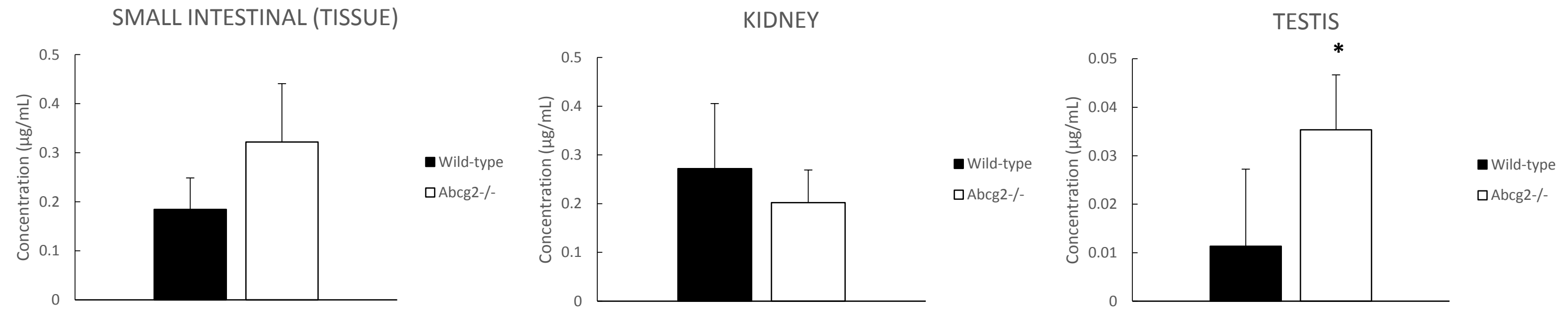
Figure 4
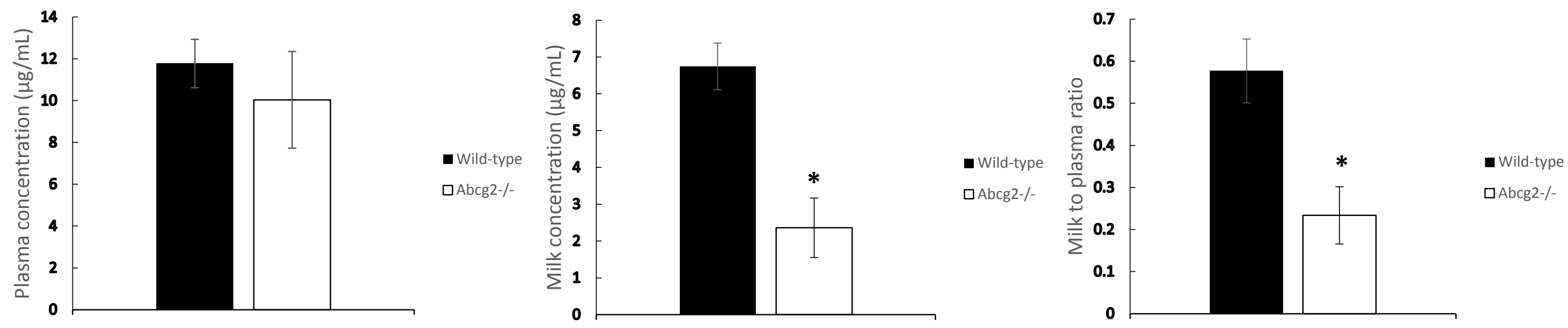


\section{CRediT author statement}

Alba M Garcia-Lino: Conceptualization, Methodology, Data curation, Formal analysis, Visualization, Investigation, Writing-Original Draft

Esther Blanco-Paniagua: Methodology, Data curation, Formal analysis, Visualization, Investigation

Elsa N Astorga-Simon: Investigation

Dafne Garcia-Mateos: Methodology, Investigation

Indira Alvarez-Fernandez: Investigation

Ana I Alvarez: Conceptualization, Methodology, Funding adquisition, Validation, Supervision, Writing-Review \& Editing

Gracia Merino: Conceptualization, Methodology, Funding adquisition, Project administration, Resources, Supervision, Writing-Review \& Editing 


\section{Graphical Abstract (for review)}
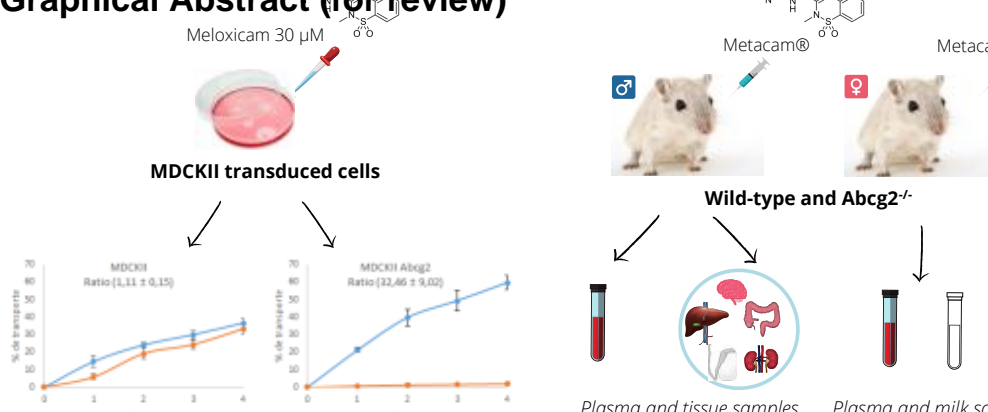

Meloxicam

Concentration

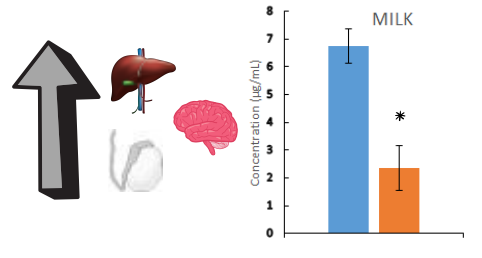

Abcg2-/- 